\title{
A Rare Cause of Bowel Obstruction in a 100-year-old Patient: Gallstone lleus
}

\section{Yaşındaki Bir Hastada Nadir Rastlanılan Bağırsak Tıkanıklığı Nedeni: Safra Taşı İleusu}

\author{
(1) Mustafa Gök1, (1) Uğur Topal2, (1) Erdoğan Mütevelli Sözüer2, @ Bahadır Öz¹, @ Muhammet Akyüz1 \\ ${ }^{1}$ Erciyes University Faculty of Medicine, Department of General Surgery, Kayseri, Turkey \\ 2Erciyes University Faculty of Medicine, Department of Surgical Oncology, Kayseri, Turkey
}

\section{HIIIIII ABSTRACT}

Gallstone ileus occurs when a gallstone passes into the intestinal system through a fistula between the gallbladder or biliary tract, and the duodenum, stomach or colon, and causes an obstruction. Although it is usually seen in advanced ages, it has rarely been reported in patients who are 100 years old. A 100-year-old female patient, without significant medical or surgical history, was admitted to the emergency department for diffuse abdominal pain, nausea, vomiting, and constipation. Abdominal computed tomography showed air in the biliary tract and obstruction in the small intestine. Patient was operated under emergency conditions. Enterolithotomy was performed and the stone was extracted. Postoperative recovery was uneventful. Bilioenteric fistulas, a major complication of chronic gallbladder diseases, usually develop secondary to intense inflammation. Patients' age, concomitant disease, clinical condition and intraoperative findings should be taken into consideration while planning the treatment. The data in the literature generally supports the employment of enterolithotomy in high-risk patients and reserves cholecystectomy and resection of the fistula for less comorbid patients with feasible anatomy.

Keywords: Cholecystoduodenal fistula, enterolithotomy, gallstone

\section{|||||||||| ÖZ}

Safra taşı ileusu safra kesesi veya safra yolları ile duodenum, mide ya da kolon arasında meydana gelen fistüle bağlı olarak safra taşlarının intestinal sisteme geçmesi ve obstrüksiyona neden olması ile oluşur. Genellikle ileri yaşlarda görülmesine rağmen litaratürde 100 yaşındaki hastalarda nadiren bildirilmiştir. Özgeçmişinde önemli bir dahili ya da cerrahi problemi olmayan 100 yaşındaki kadın hasta; acil servise yaygın karın ağrısı, bulantı, kusma ve kabızlık nedeniyle başvurdu. Abdominal bilgisayarlı tomografisinde safra yollarında hava ve ince bağırsak düzeyinde obstrüksiyon vardı. Acil şartlarda opere edildi. Enrolitotomi yapıldı taş eksaktre edildi, postoperatif dönemi sorunsuz geçti. Kronik safra kesesi hastalıklarının önemli bir komplikasyonu olan biliyoenterik fistüller ortalama yoğun inflamasyona sekonder olarak gelişirler. Tedavi planlanmasında, yaşı, yandaş hastalıkları, klinik durumu ve intraoperatif bulgular göz önünde bulundurulmaktadır. Literatürde genel olarak yüksek riskli hastalarda enterolitotomi istihdamını ve daha az komorbid olan hastalar için kolesistektomiyi fistül rezeksiyonunu desteklemektedir.

Anahtar Kelimeler: Kolesistoduodanal fistül, enterolitotomi, safra taşı

\section{Introduction}

Bartholin first described by gallstone ileus in 1654, which is a rare cause of small intestinal obstruction. It happens when a gallstone passes through the intestinal system along a fistula between the gallbladder or biliary tract and the duodenum, stomach or colon and causes obstruction. ${ }^{1}$
In patients under 65 years of age, gallstone ileus is the cause of less than $4 \%$ of intestinal obstruction, and this incidence increases to $25 \%$ in patients over 65 years of age. The proportion of women to men is 3.5-3.6:1, and patients are typically over 65 years of age. ${ }^{2}$

The gallstone ileus-related mortality rate ranges from $12 \%$ to $27 \%$, and the morbidity rate reaches $50 \%$. $^{3}$ Patients present

Address for Correspondence/Yazışma Adresi: Uğur Topal, MD, 
with nonspecific symptoms, such as abdominal pain and vomiting. Typically, laboratory tests are nonspecific. Even though $30-40 \%$ of patients can be diagnosed radiologically preoperatively, it is mostly done during the surgery. ${ }^{4}$ Radiology shows the pathognomonic triad of pneumobilia, small bowel obstruction and ectopic gallstone. Thus, the ideal treatment of gallstone ileus remains controversial. ${ }^{2}$

In this case, we evaluated our approach to a 100-year-old patient with preoperative diagnosis of gallstone ileus.

\section{Case Report}

With abdominal pain, nausea, vomiting and abdominal distention, a 100-year-old Middle Eastern female patient was admitted to the emergency room. Her complaints began 2 days earlier, and for the last 2 days, she hadn't passed gas/stool. Her medical history revealed that she had primary hypertension. In addition, she did not have a history of previous abdominal surgery but had a history of hospitalization due to acute cholecystitis. Additionally, previous ultrasound examination had revealed gallstones in the gallbladder.

The patient had no contributing family or psychosocial history or history of smoking or other metabolic diseases. Physical examination showed abdominal distention and diffuse sensitivity with palpation. During auscultation, no intestinal sounds could be obtained in four quadrants of the abdomen, and tympanism was observed on all four quadrants of the abdomen with percussion. Further, during rectal examination, the rectal ampulla was empty, and no palpable mass was detected. The body temperature of the patient was $38^{\circ} \mathrm{C}$, blood pressure was $100 / 60 \mathrm{mmHg}$, pulse was $115 /$ minute, and body mass index was 28 . The following values were obtained in laboratory analysis: white blood cell count $=1 / 4,900 / \mathrm{mm}^{3}$, aspartate transaminase $=$ $116.7 \mathrm{u} / \mathrm{L}$, alanine transaminase $=112.9 \mathrm{u} / \mathrm{L}$, glucose $=77$ $\mathrm{mg} / \mathrm{dL}$, chloride $=101.4 \mathrm{mmol} / \mathrm{L}$, blood urea nitrogen $=25.4$ $\mathrm{mg} / \mathrm{dL}$, creatinine $=1.45 \mathrm{mg} / \mathrm{dL}$, sodium $=130 \mathrm{mmol} / \mathrm{L}$, potassium $=3.05 \mathrm{mmol} / \mathrm{L}$, total bilirubin $=0.10 \mathrm{mg} / \mathrm{dL}$, direct bilirubin $=0.10 \mathrm{mg} / \mathrm{dL}$, amylase $=43 \mathrm{U} / \mathrm{L}$, gamma-glutamyl transpeptidase $=243 \mathrm{u} / \mathrm{L}$, alkaline phosphatase $=285 \mathrm{u} / \mathrm{L}$, lactate dehydrogenase $=429 \mathrm{u} / \mathrm{L}$, and C-reactive protein $=18$ $\mathrm{mg} / \mathrm{L}$. On the other hand, other parameters were normal.

In abdominal ultrasonography, the integrity of the stone wall inside the gallbladder was impaired. Further, oral and IV contrast computed tomography revealed air in the gallbladder and intrahepatic bile ducts, and there were signs of obstruction of the ileus in the small bowel level (Figure 1).

The patient was admitted to the intensive care unit. Before surgery, intravenous fluid and antibiotics (piperacillin/ tazobactam) were administered. The patient also underwent nasogastric intubation and correction of electrolyte disturbances.

The patient then underwent emergency surgery. After anaesthetic clearance, an emergency laparotomy was performed under general anaesthesia with a diagnosis of gallstone ileus. A large 4-cm palpable gallstone was found in the $60^{\text {th }} \mathrm{cm}$ of the terminal ileum. The technique of choice was the removal of the stone via enterotomy, then a longitudinal incision was performed on the antimesenteric border proximal to the site of impaction, and the gallstone was milked proximally and removed (Figure 2).

During enterotomy, a general survey of the abdomen was conducted where no signs of malignancy were identified, and it was closed in two layers because the patient's tissues

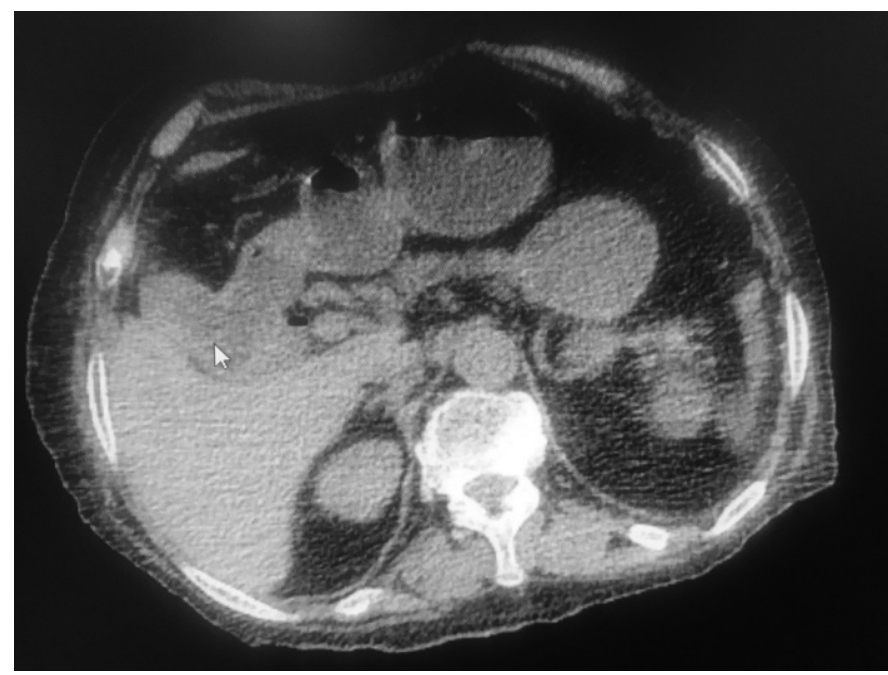

Figure 1. CT scan showed air in the gallbladder and intrahepatic bile ducts

CT: Computed tomography

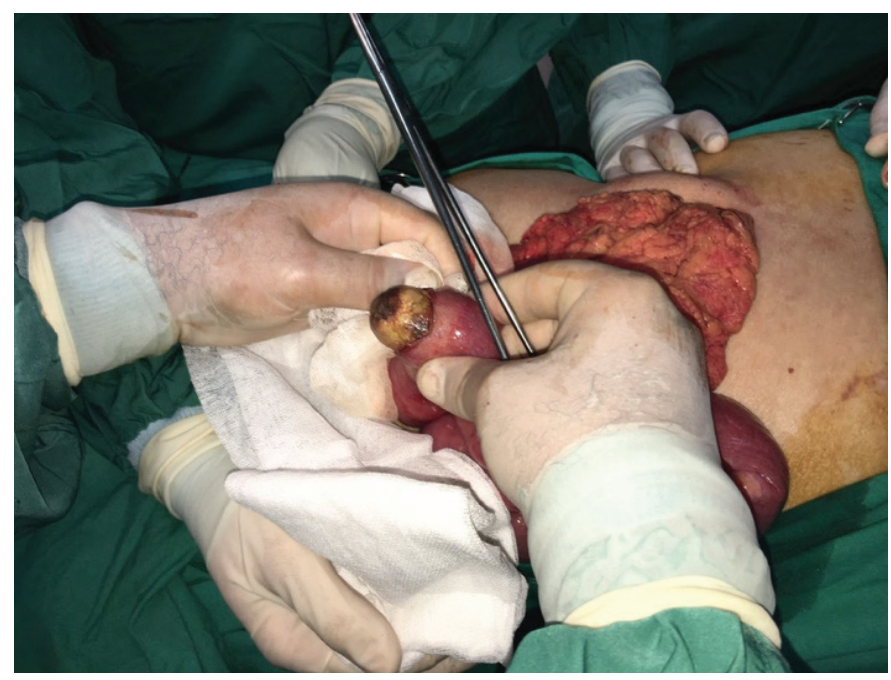

Figure 2. The gallstone was removed and the enterotomy was repaired in two layers 
in the upper right quadrant were oedematous and fragile, which appeared to be inflamed and compatible with a cholecystoduodenal fistula. Considering the age of the patient and comorbid factors, no attempt was made on the cholecystoduodenal fistula and gallbladder. The final pathology of the specimen was reported as a gallstone: 12.5 gr, olive green-yellow coloured, and ovoid shaped, which measured $4 \times 3.2 \times 2.5 \mathrm{~cm}$ (Figure 3).

The duration of the surgery was 1 hour and 45 minutes, with a blood loss of $100 \mathrm{~mL}$. Moreover, the patient was followed up in the postoperative intensive care unit. Postoperative follow-up was followed by antibiotic therapy (piperacillin/ tazobactam), intravenous fluid, analgesics (paracetamol) and enoxaparin sodium for thrombosis prophylaxis. Antiemetics were administered, and after gastrointestinal passage was achieved, the oral intake was started.

On the 8th postoperative day, the patient had an uneventful postoperative course and was discharged home. The patient had no specific postoperative complications, and there was no development of wound complications. Therefore, we did not need a rediscovery/revision surgery. We have not experienced postoperative 30-day and long-term morbidity/ mortality. Further, 10 days after discharge, the patient was followed up as an outpatient, and an infection was discovered at the incision site, so wound care was administered. During the 1-month follow-up, no recurring complaints were observed. After 6 months, another follow-up was conducted. Moreover, in terms of biliary complications, the patient should be closely monitored.

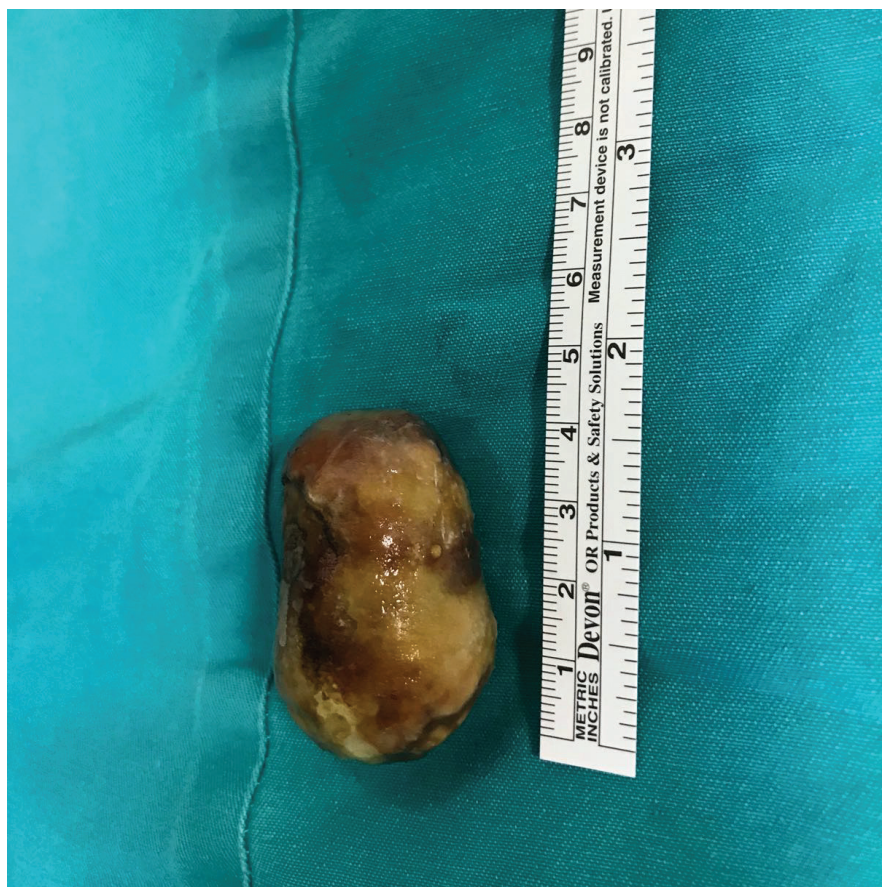

Figure 3. The appearance of the gallstone after removal by enterotomy

\section{Discussion}

Bilioenteric fistulas, a significant complication of chronic gallbladder diseases, usually develop secondary to intense inflammation. The key mechanism is the development of abnormal epithelial connections between two hollow organs by mass effect and secondary inflammation. ${ }^{5}$

Gallstone ileus is observed in $0.3-0.5 \%$ of all cases of cholelithiasis. In gallstone ileus, the gallbladder stone enters the intestinal tract through a fistula. ${ }^{1}$ When we look at the literature, the localization of the fistula is most often cholecystoduodenal with $68 \%$, while it is $5 \%$ cholecystocolonic and $2.5 \%$ cholecystoduodenocholic. In addition, the localization of the gallstone has been reported as $64 \%$ terminal ileum, $23 \%$ proximal ileum and jejunum, $4 \%$ colon and $1 \%$ stomach. ${ }^{6}$

In our case, a cholecystoduodenal fistula was present, and the gallstone was found in the terminal ileum. With the imaging methods used in diagnosis, the accuracy rates can be increased for preoperative diagnosis. The imaging diagnostic criteria for gallstone ileus are called "Rigler's triad" and consist of the presence of a radiopaque stone (presenting in less than $10 \%$ of cases), pneumobilia (GottaMentschler sign) and bowel loop distention. Moreover, two of these three signs are diagnostic. ${ }^{2,7}$ The use of X-rays in conjunction with abdominal ultrasound increases sensitivity to $74 \%$ for a gallstone diagnosis. ${ }^{8}$ The contrast computed tomography (CT) scan is recognized as the gold standard method for the diagnosis of gallstone ileus and is reported to have a sensitivity over $90 \%$ in the literature. ${ }^{9}$ In the literature, a study comparing direct abdominal X-ray, abdominal ultrasonography and abdominal $\mathrm{CT}$ for gallstone ileus found that Rigler's triad is present in $14.8 \%$ of plain abdominal film, in $11.11 \%$ of abdominal US and in $77.78 \%$ of abdominal CT. ${ }^{9}$

Treatment options include enterolithotomy (stone extraction, cholecystectomy, fistula tract excision) or twostage surgical enterolithotomy and biliary tract surgery. ${ }^{10,11}$ Because of the age and comorbidities of the patient, we decided to perform enterolithotomy as the treatment option. In the literature, in a series comparing single-stage surgery with enterolithotomy, the mortality rate of enterolithotomy was found to be lower (11.7\%) compared to single-stage surgery $(16.9 \%){ }^{3}$

Enterolithotomy can be applied easily and rapidly in patients with an advanced age and in the presence of comorbid disease. However, recurrent gallstone ileus, acute cholecystitis, recurrent cholangitis and the persistence of the risk of gallbladder cancer are the disadvantages of this technique. ${ }^{10}$ 
Laparoscopic procedures can be an alternative method, but it would be necessary to have a surgeon with specialist expertise in advanced laparoscopic surgery. Moreover, the potential advantages are a shorter hospital stay and reduced laparotomy-associated morbidity. ${ }^{12}$ A valid alternative approach is the endoscopic treatment of gallstone ileus. In the literature, endoscopic mechanical lithotripsy and transrectal endoscopic treatment without lithotripsy have been successfully applied. In addition, ultrasoundguided extracorporeal shock wave lithotripsy has also been proposed as a noninvasive alternative to surgery to fragment the stone and solve the sub-occlusion. ${ }^{13,14,15}$

Management of gallstone ileus is mainly surgical. Gallstones should be considered in the differential diagnosis of elderly women with a diagnosis of mechanical intestinal obstruction. The age, concomitant disease, clinical condition and intraoperative findings of patients should be taken into consideration in treatment planning.

Informed Consent: Informed consents was obtained from the patient.

Peer-review: Externally and internally peer reviewed.

\section{Authorship Contributions}

Surgical and Medical Practices: M.G., U.T., E.M.S., B.Ö., M.A., Concept: M.G., U.T., B.Ö.,

Design: M.G., U.T., Data Collection or Processing: U.T., B.Ö., M.A., Analysis or Interpretation: M.G., U.T., M.S., Literature Search: U.T., M.A., Writing: M.G., U.T., E.M.S.

Conflict of Interest: No conflict of interest was declared by the authors.

Financial Disclosure: The authors declared that this study received no financial support.

\section{References}

1. Doko M, Zovak M, Kopljar M, Glavan E, Ljubicic N, Hochstädter H. Comparison of surgical treatments of gallstone ileus: preliminary report. World J Surg 2003;27:400-404.

2. Ploneda-Valencia CF, Gallo-Morales M, Rinchon C, Navarro-Muñiz E, Bautista-López CA, de la Cerda-Trujillo LF, Rea-Azpeitia LA, LópezLizarraga CR. Gallstone ileus: An overview of the literature. Rev Gastroenterol Mex 2017;82:248-254.

3. Alexiou K, Ioannidis A, Sikalias N, Konstantinidou E, Fotopoulos A, Karanikas I, Economou N. Gallstone Ileus: A Case Report and Our Clinic's Experience. Surg Sci 2014;5:10-14.

4. Pergel A, Yücel AF, Karaca AS, Aydın İ, and Şahin DA. İleusun nadir bir sebebi: safra taşı ileusu. İnönü Üniv Tip Fak Derg 2010;17:395-397.

5. 5.Yüksel O, Şakrak Ö, Tatlıcıoğlu E, Şahin T, Bostancı H. Kolesistoduodenal fistül: Üç olgu sunumu. Turkish J Surg 2007;23:69-72.

6. Dalcı K, Ülkü A, Rencüzoğulları A, Eray IC YO. İleri yaş hastada dev safra taşına bağlı intestinal obstrüksiyon: olgu sunumu. Causa Pedia 2014;3:841.

7. Rigler LG, Borman CN, And Noble JF. Gallstone Obstruction. J Am Med Assoc 1941;117:1753

8. Laméris W, van Randen A, van Es HW, van Heesewijk JPM, van Ramshorst B, Bouma WH, ten Hove W, van Leeuwen MS, van Keulen EM, Dijkgraaf MGW, Bossuyt PMM, Boermeester MA, Stoker J. Imaging strategies for detection of urgent conditions in patients with acute abdominal pain: diagnostic accuracy study. BMJ 2009;338:b2431.

9. Lassandro F, Gagliardi N, Scuderi M, Pinto A, Gatta G, Mazzeo R. Gallstone ileus analysis of radiological findings in 27 patients. Eur J Radiol 2004:50:23-29.

10. Spaziani E, Picchio M, Di Filippo A, De Angelis F, Marino G, Stagnitti F. Gallstone ileus. Report of two cases. Ann Ital Chir 2010;81:53-55.

11. Koç B, Tutal F, Karahan SR, Adaş G, Arslan UA. Rare intestinal obstruction reason in elderly patients: Gallstone ileus. Turk J Colorectal Dis 2013;23:55-58.

12. Allen JW, McCurry T, Rivas H, Cacchione RN. Totally laparoscopic management of gallstone ileus. Surg Endosc 2003;17:352-352.

13. Pezzoli A, Maimone A, Fusetti N, Pizzo E. Gallstone ileus treated with nonsurgical conservative methods: a case report. J Med Case Rep 2015;9:1-5.

14. Lafitte S, Hanafi R, Browet F. Transrectal endoscopic treatment of gallstone ileus J Visc Surg 2019;156:269-270.

15. Balzarini M, Broglia L, Comi G, Calcara C. Large bowel obstruction due to a big gallstone successfully treated with endoscopic mechanical lithotripsy. Case Rep Gastrointest Med 2015;2015:798746. 